JKEP

Vol 5, No 1, Mei 2020

ISSN: 2354-6042 (Print)

ISSN : 2354-6050 (Online)

\title{
Faktor - Faktor Yang Berhubungan Dengan Hipertensi Pada Usia Dewasa
}

\author{
Ni Luh Putu Ekarini, ${ }^{1}$ Jathu Dwi Wahyuni ${ }^{2}$, Dita Sulistyowati ${ }^{3}$ \\ Jurusan Keperawatan Poltekkes Kemenkes Jakarta III \\ Email : ekaputu98@yahoo.com
}

\author{
Artikel history \\ Dikirim, April 30 th, 2020 \\ Ditinjau, May $6^{\text {th }}, 2020$ \\ Diterima, May $8^{\text {th }}, 2020$
}

\begin{abstract}
Hypertension is a non-communicable disease with an increasing number of events every year. There are two risk factors for hypertension, namely risk factors that cannot be modified, such as age, sex and genetics, and modifiable risk factors such as obesity, smoking, lack of physical activity, excessive salt consumption, dyslipidemia, alcohol consumption and psychososis and stress. This study aims to obtain an overview of the factors associated with hypertension in adulthood. The research design used was descriptive analytic research with cross-sectional studies. The number of samples is 70 people with simple random sampling technique. Data analysis used univariate, bivariate (chi square) and multivariate (multiple logistic regression) component analyzes. Multivariate analysis showed that the variable that was significantly related to the occurrence of hypertension was the age variable (pvalue $=0.009$ ). Variable overweight and physical activity as confounding variables. The analysis results obtained OR from the age variable is 2.9, meaning that patients in middle to upper adult age will experience hypertension 2.9 times higher than young adult patients after being controlled by obesity and physical activity variables. Recommendations from the results of this study are expected to be able to provide health care institutions that emphasize the promotive and preventive aspects of patients who have a history of hypertension.
\end{abstract}

Keywords: hypertension, risk factors

\begin{abstract}
ABSTRAK
Hipertensi menjadi salah satu jenis penyakit tidak menular dengan angka kejadian yang terus meningkat setiap tahunnya. Faktor risiko hipertensi ada dua yaitu faktor risiko yang tidak dapat dimodifikasi seperti usia, jenis kelamin dan genetik serta faktor risiko yang dapat dimodifikasi seperti kegemukan, merokok, kurang aktifitas fisik, konsumsi garam berlebih, dislipidemia, konsumsi alkohol serta psikososisal dan stress. Penelitian ini bertujuan untuk memperoleh gambaran tentang faktor-faktor yang berhubungan dengan hipertensi pada usia dewasa. Desain penelitian yang digunakan adalah penelitian deskriptif analitik dengan studi cross-sectional. Jumlah sampel adalah 70 orang dengan teknik pengambilan simple random sampling. Analisis data menggunakan analisis
\end{abstract}


komponen univariat, bivariat (chi square) dan multivariat (regresi logistik ganda). Analisis multivariat menunjukkan bahwa variabel yang berhubungan bermakna dengan terjadinya hipertensi adalah variabel usia (pvalue $=0.009$ ). Variabel kegemukan dan aktifitas fisik sebagai variabel konfonding. Hasil analisis didapatkan OR dari variabel usia adalah 2.9, artinya pasien pada usia dewasa menengah ke atas akan mengalami hipertensi 2.9 kali lebih tinggi dibandingkan pasien dewasa muda setelah dikontrol variabel kegemukan dan aktifitas fisik. Rekomendasi dari hasil penelitian ini diharapkan institusi pelayanan kesehatan mampu memberikan asuhan yang menekankan pada aspek promotif dan preventif terhadap pasien yang mempunyai riwayat hipertens.

Kata kunci : hipertensi, faktor risiko

\section{PENDAHULUAN}

Pada kondisi kehidupan saat ini banyak terjadi pergeseran pola penyakit, begitu juga di Indonesia terjadi pergeseran dari penyakit menular menjadi penyakit tidak menular (PTM). Prevalensi PTM meningkat salah satunya diakibatkan karena gaya hidup tidak sehat, bisa dipacu oleh makin meningkatnya fenomena urbanisasi, modernisasi dan globalisasi. Selain karena meningkatnya PTM, terjadinya perubahan piramida jumlah penduduk juga bisa menjadi salah satu penyebab hipertensi. Usia harapan hidup bertambah seiring dengan peningkatan sosio-ekonomi dan pelayanan kesehatan sehingga dapat menjadi salah satu pemicu bertambahnya penyakit akibat peningkatan usia harapan hidup (degeneratif) (Kemenkes Direktorat PPTM Subdit Pengendalian Penyakit Jantung Dan Pembuluh Darah, 2013).
Hipertensi adalah salah satu jenis penyakit tidak menular dengan angka kejadian yang terus meningkat setiap tahun walaupun tindakan promotif dan preventif sudah banyak dikembangkan mengikuti kemajuan ilmu pengetahuan dan teknologi. Hipertensi merupakan permasalahan kesehatan yang harus ditangani secara serius. Prevalensi hipertensi berbeda-beda di setiap Negara. Indonesia menjadi salah satu negara dengan jumlah penduduk hipertensi yang tinggi dan selalu meningkat setiap tahunnya (Rilantono, 2012). Hipertensi merupakan suatu kondisi dimana tekanan darah sistolik $\geq$ $140 \mathrm{mmHg}$ dan atau tekanan darah diastolik $\geq 90 \mathrm{mmHg}(C D C$ dikutip dalam Black, 2009).

Hipertensi merupakan penyakit tidak menular yang jarang menimbulkan gejala pada penderitanya. Seseorang 
bisa terdiagnosis hipertensi dari beberapa aspek pemeriksaan. Jakarta sebagai ibu kota negara dengan berbagai permasalahannya masih mempunyai angka kejadian hipertensi yang terus meningkat setiap tahunnya. Kejadian hipertensi di Jakarta didapatkan melalui kuisioner terdiagnosis tenaga kesehatan $10 \%$, diagnosis tenaga kesehatan atau sedang minum obat $10.1 \%$ dan dari hasil pengukuran 20\% (Riskesdas, 2013).

Berdasarkan catatan Badan Kesehatan Dunia

(World

Health

Organization/WHO) pada tahun 2011, dua pertiga penduduk negara berkembang dengan penghasilan rendah-sedang menjadi kelompok risiko terbesar yang mengalami hipertensi dari satu milyar orang di_dunia yang menderita hipertensi. Prediksi pada tahun 2025 nanti, sekitar 29\% orang dewasa di seluruh dunia menderita hipertensi. Masalah hipertensi harus diperhatikan secara serius karena dapat menyebabkan kematian sekitar 8 juta orang setiap tahun dan 1,5 juta kematian tersebut terjadi di Asia Tenggara (Kemenkes Direktorat PPTM Subdit Pengendalian Penyakit Jantung Dan Pembuluh Darah, 2013).

Hipertensi merupakan faktor risiko yang dapat dimodifikasi untuk mencegah kesakitan dan kematian akibat masalah kardiovaskuler di seluruh dunia. Prevalensi hipertensi dapat meningkat karena faktor usia yaitu pada orang dengan usia diatas 65 tahun. Pada dua dekade belakangan ini, orang dengan usia lebih dari 65 tahun di negara-negara barat menderita hipertensi. Usia berhubungan dengan disfungsi endotelial dan meningkatnya kekakuan arteri pada hipertensi, khususnya hipertensi sistolik pada usia dewasa tua. Selanjutnya, kesulitan merawat hipertensi umumnya terjadi pada usia dewasa tua karena meningkatnya penggunaan obat-obat farmakologi seperti obat Non Steroid Anti Inflamasi (NSID) dan kortikosteroid yang dapat meningkatkan tekanan darah (Volpe \& Tocci, 2013).

Hipertensi adalah penyakit kronis yang umum dan menjadi faktor risiko kunci bagi perkembangan penyakit kardiovaskuler, seperti stroke, infark miokard dan gagal jantung. Penentuan prevalensi hipertensi dan prehipertensi bisa diketahui dari jenis kelamin, usia, dan agama. Faktor risiko bisa diketahui 
dari usia, body mass index (BMI)/obesitas, status merokok, lipidemia, dan diabetas (Jolly, et.al.,2015).

Faktor risiko hipertensi pada penduduk asli Alaska Barat menemukan bahwa hipertensi meningkat dengan bertambahnya usia, dimana $50 \%$ responden berusia 55-64 tahun dan hampir $70 \%$ dari responden tersebut berusia 65 tahun dan lebih. Faktor risiko lain yang berkaitan dengan kejadian hipertensi selain usia adalah obesitas dan adanya peningkatan gula darah puasa (Jolly, et.al.(2015).

Stres psikososial adalah faktor risiko hipertensi yang mempengaruhi respon pada pasien dengan penyakit psikiatri karena menurunkan efektifitas perawatan hipertensi. Stresor sosial (kesulitan masa kecil, kejadian hidup yang membuat stres, dan kesulitan yang dialami jangka panjang seperti yang disebabkan oleh perkerjaan, keuangan atau masalah yang berhubungan dengan pasangan) merupakan faktor penting yang berkontribusi pada proses perkembangan kesehatan fisik. Belakangan ini, pengalaman stres psikososial yang kronis pada usia dewasa juga merupakan faktor risiko hipertensi (Wainwright,et.al., 2013).

Usia dewasa merupakan kelompok risiko yang rentan mengalami hipertensi di wilayah kerja Puskesmas II pada bulan Mei 2012 sebesar 38\%. Orang dengan risiko hipertensi pada usia dewasa di wilayah kerja Puskesmas II pada bulan Mei 2012 yaitu sebesar $38 \%$. Kecenderungan angka kejadian hipertensi lebih banyak terjadi pada laki-laki (39.7\%) pada kelompok usia diatas 60 tahun (54.5\%), kurang aktifitas fisik (47.7\%), dan obesitas (42.9\%). Tingginya prevalensi hipertensi pada kelompok usia dewasa dengan aktifitas rendah dan kegemukan perlu dilakukan tindakan preventif dan promotif melalui kegiatan senam dan promosi kesehatan (Tirka \& Sudhana, 2012). Faktor risiko yang berhubungan dengan kejadian hipertensi antara lain aktifitas fisik ( $\mathrm{p}=0.000)$, obesitas $(\mathrm{p}=$ 0.002), dan stres $(\mathrm{p}=0.016)$ (Sapitri, Suryanto \& Ristua, 2016).

Berdasarkan etiologinya ada dua faktor risiko yang menyebabkan hipertensi yaitu faktor risiko yang tidak dapat dimodifikasi seperti usia, jenis kelamin dan keturunan/genetic serta faktor risiko 
yang dapat dimodifikasi seperti kegemukan, merokok, kurang aktifitas fisik, konsumsi garam berlebih, dislipidemia, konsumsi alkohol serta psikososial dan stress. (Lewis,et.al.,2007). Hipertensi merupakan penyakit kronis yang sering muncul tanpa gejala. Kondisi klinis ini memerlukan terapi jangka panjang yang terus menerus agar tekanan darah tetap terkontrol.-Kejadian hipertensi lebih tinggi pada usia lanjut, ditambah adanya fakta resisten terhadap obat anti hipertensi sehingga mendukung terjadinya penyakit kardiovaskuler akut (Volpe \& Tocci, 2013).

Belakangan ini kejadian hipertensi dan komplikasinya semakin meningkat bisa berakibat fatal bila tidak segera dicegah dan ditangani dengan segera terutama pada usia dewasa. Usia dewasa dimulai dari usia diatas 18 tahun mempunyai risiko tinggi mengalami hipertensi berkaitan erat dengan pola hidup. Usia dewasa ini akan dibagi lagi dalam tiga tahapan rentang usia yaitu dewasa muda (18-40 tahun), dewasa menengah (40-65 tahun) dan terakhir dewasa tua dengan usia diatas 65 tahun. Usia dewasa menjadi faktor risiko yang berpengaruh besar dengan hipertensi karena seiring bertambahnya usia kemampuan dan mekanisme tubuh meningkat dan terjadi penurunan secara perlahan. Usia dewasa merupakan kelompok risiko yang rentan mengalami hipertensi dan hipertensi meningkat dengan bertambahnya usia. Oleh karena itu penelitian terkait faktor-faktor yang berhubungan dengan hipertensi pada kelompok usia dewasa yang secara teori mempunyai risiko paling tinggi perlu dilaksanakan.

\section{METODE}

Penelitian ini adalah penelitian kuantitatif dengan metode penelitian deskriptif analitik rancangan cross sectional. Penelitian ini diawali dengan mengidentifikasi pasien usia dewasa yang berobat ke Puskesmas Rawamangun Jakarta Timur. Waktu penelitian akan dilaksanakan pada bulan Agustus - Oktober 2016 responden antara lain $\mathrm{p},, \mathrm{d}$, responden antara lain p serta Alat mengumpulkan data berupa kuisioner atau instrumen. Instrumen sebelum digunakan dalam penelitian dilakukan uji instrumen. Pada proses pelaksanaan penelitian didahului dengan memberikan penjelasan kepada responden terkait tujuan, manfaat dan prosedur dalam pelaksanaan penelitian. Responden yang setuju akan 
menandatangani lembar persetujuan sebagai informed consent. Dalam penelitian ini responden dilindungi dengan memperhatikan aspek-aspek right to self determination, right to privacy, right to anonymity and confidentiality, right to fair treatment dan protection from discomfort and harm (American Nurses Association (ANA), 1985).

Pengambilan sampel dilakukan dengan menggunakan metode probability sampling yaitu simple random sampling dengan cara menghitung dahulu jumlah subyek dalam populasi (terjangkau) yang akan dipilih sampelnya. Jumlah responden yang mengikuti penelitian ini yaitu sebanyak 70 orang. Analisis data penelitian menggunakan analisis komponen univariat, bivariat (chi square) dan multivariat (regresi logistik ganda).

Keterangan Persetujuan Etik dari Komisi Etik Penelitian Kesehatan Poltekkes Kemenkes Jakarta III No. 069/KEPK-PKKJ3/05/2016 tanggal 20 Mei 2016.

\section{HASIL DAN PEMBAHASAN}

Tabel 1

Data Distribusi Responden Di Puskesmas Rawamangun Jakarta Timur, Oktober 2016 ( $\mathrm{n}=70)$

\begin{tabular}{lccc}
\hline \multicolumn{1}{c}{ Variabel } & Mean & SD & Min - Maks \\
Usia & 51.43 & 14.6 & $18-78$ \\
Tekanan darah sistol & 127 & 15.85 & $90-170$ \\
Tekanan darah diastol & 83 & 7.75 & $70-100$ \\
Frekuensi nadi & 77 & 7.72 & $56-92$ \\
\hline
\end{tabular}

Tabel 2

Faktor-Faktor Yang Berhubungan Dengan Hipertensi

di Puskesmas Rawamangun Jakarta Timur, Agustus $2016(\mathrm{n}=70)$

\begin{tabular}{|c|c|c|c|c|c|c|c|}
\hline \multirow[t]{4}{*}{ No. } & \multirow[t]{4}{*}{ Variabel } & \multicolumn{4}{|c|}{ Klasifikasi Hipertensi } & \multirow{4}{*}{$\begin{array}{c}\mathrm{P} \\
\text { value }\end{array}$} & \multirow{4}{*}{$\begin{array}{c}\text { OR } \\
(95 \% \mathrm{CI})\end{array}$} \\
\hline & & & lak & & tensi & & \\
\hline & & \multicolumn{4}{|c|}{ Hipertensi } & & \\
\hline & & $\mathrm{n}$ & $\%$ & $\mathrm{n}$ & $\%$ & & \\
\hline \multirow[t]{6}{*}{1.} & Usia & & & & & & \\
\hline & Dewasa Muda (18-40 tahun) & 17 & 85 & 3 & 15 & $0.016^{*}$ & \\
\hline & Dewasa Menengah (41-65 & 28 & 77.8 & 8 & 22.2 & & 1.619 \\
\hline & tahun) & 6 & 42.9 & 8 & 57.1 & & $(0.377-6.953)$ \\
\hline & Dewasa Tua (lebih dari 65 & & & & & & 7.556 \\
\hline & tahun) & & & & & & $(1.494-38.208)$ \\
\hline \multirow[t]{3}{*}{2.} & Jenis Kelamin & & & & & & \\
\hline & Laki-laki & 18 & 72 & 7 & 28 & 1.000 & 0.935 \\
\hline & Perempuan & 33 & 73.3 & 12 & 26.7 & & $(0.313-2.795)$ \\
\hline
\end{tabular}




\begin{tabular}{|c|c|c|c|c|c|c|c|}
\hline \multirow[t]{3}{*}{3.} & Genetik (Keluarga) & & & & & \multirow{3}{*}{1.000} & \multirow{3}{*}{$\begin{array}{c}1.096 \\
(0.381-3.150)\end{array}$} \\
\hline & Tidak ada riwayat keluarga & 28 & 73.7 & 10 & 26.3 & & \\
\hline & Ada riwayat keluarga & 23 & 71.9 & 9 & 28.1 & & \\
\hline \multirow[t]{3}{*}{4.} & Kegemukan & & & & & \multirow{3}{*}{0.259} & \\
\hline & Tidak kegemukan & 20 & 64.5 & 11 & 35.5 & & 0.469 \\
\hline & Kegemukan & 31 & 79.5 & 8 & 20.5 & & $(0.161-1.368)$ \\
\hline \multirow[t]{3}{*}{5.} & Merokok & & & & & \multirow{3}{*}{0.665} & \\
\hline & Tidak pernah merokok & 45 & 71.4 & 18 & 28.6 & & 0.417 \\
\hline & Pernah merokok & 6 & 85.7 & 1 & 14.3 & & $(0.047-3.710)$ \\
\hline \multirow[t]{3}{*}{6.} & Kurang aktifitas fisik & & & & & \multirow{3}{*}{$0.049 *$} & \\
\hline & Aktifitas kurang & 29 & 64.4 & 16 & 35.6 & & 0.247 \\
\hline & Aktigitas cukup & 22 & 88 & 3 & 12 & & $(0.064-0.955)$ \\
\hline \multirow[t]{5}{*}{7.} & Konsumsi garam berlebihan & & & & & \multirow{4}{*}{0.169} & \\
\hline & Tidak pernah & 16 & 72.7 & 6 & 27.3 & & \\
\hline & Jarang & 27 & 67.5 & 13 & 32.5 & & 1.284 \\
\hline & & 8 & 100 & 0 & 0 & & $(0.407-4.047)$ \\
\hline & Sering & & & & & & $\begin{array}{c}0.000 \\
(0.000-\quad)\end{array}$ \\
\hline \multirow[t]{3}{*}{8.} & Psikososial dan stres & & & & & \multirow{3}{*}{0.621} & \\
\hline & Tidak ada dampak psikologis & 32 & 76.2 & 10 & 23.8 & & 1.516 \\
\hline & Ada dampak psikologis & 19 & 67.9 & 9 & 32.1 & & $(0.523-4.395)$ \\
\hline
\end{tabular}

Tabel 3

Variabel Paling Dominan Yang Berhubungan De gan Hipertensi

Di Puskesmas Rawamangun Jakarta Timur, Oktober $2016(\mathrm{n}=70)$

\begin{tabular}{|c|c|c|c|c|c|c|c|}
\hline No. & Variabel & B & Wald & Sig. & OR & \multicolumn{2}{|c|}{$\begin{array}{l}95 \% \text { C.I. for } \\
\operatorname{Exp}(\mathrm{B})\end{array}$} \\
\hline 1. & Usia & 1.073 & 6.072 & 0.014 & 2.924 & $\begin{array}{c}\text { Lower } \\
1.246\end{array}$ & $\begin{array}{l}\text { Upper } \\
6.866\end{array}$ \\
\hline
\end{tabular}

Rata-rata usia responden adalah 51.43 tahun, dengan usia termuda 18 tahun dan usia tertua 78 tahun. Sebagian besar tidak ingat mengalami hipertensi sejak kapan. Rata-rata usia responden berada pada usia dewasa menengah, sesuai dengan teori yang menyampaikan bahwa meningkatnya usia risiko hipertensi juga meningkat. Usia berhubungan dengan disfungsi endotelial dan meningkatnya kekakuan arteri pada hipertensi, khususnya hipertensi sistolik pada usia dewasa tua. Selanjutnya, kesulitan merawat hipertensi umumnya terjadi pada usia dewasa tua karena meningkatnya penggunaan obat-obat farmakologi seperti obat Non Steroid Anti Inflamasi 
(NSID) dan kortikosteroid yang dapat meningkatkan tekanan darah (Volpe \& Tocci, 2013). Berdasarkan Laporan Hasil Riset Kesehatan Dasar (RISKESDAS) Indonesia-Tahun 2013, ada kecenderungan prevalensi penyakit hipertensi meningkat dengan bertambahnya umur yaitu diatas usia dewasa menengah. Hal ini sejalan dengan hasil penelitian dimana responden yang mengalami hipertensi sebagian besar berusia diatas 41 tahun (dewasa menengah). Prevalensi hipertensi di DKI Jakarta cukup tinggi berdasarkan hasil Riskesdas baik dari hasil kuisioner terdiagnosis tenaga kesehatan, yang terdiagnosis tenaga kesehatan dan minum obat maupun hipertensi dari hasil pengukuran dengan jumlah sebanyak 20\%. Setiap tahunnya, angka kejadian hipertensi di DKI masih tinggi dan terus meningkat. Hasil penelitian ini sesuai dengan hasil penelitian oleh Ardiani, et.al (2015) yang menunjukkan bahwa usia lanjut berisiko mengalami hipertensi $(\mathrm{p}=0.028), \quad$ Mahendrappa (2014) $(\mathrm{p}=0.015) \quad$ dan Adriani (2013) $(\mathrm{p}=0.000)$.

Jenis kelamin responden didominasi oleh perempuan (64.3\%). Berdasarkan laporan RISKESDAS Indonesia-Tahun 2013, prevalensi hipertensi juga didominasi oleh perempuan. Jenis kelamin mempunyai pengaruh yang besar pada kejadian hipertensi. Diketahui bahwa laki-laki mempunyai risiko 2.3 kali lebih banyak mengalami peningkatan tekanan darah sistolik dibandingkan dengan perempuan, karena diperkirakan laki-laki mempunyai gaya hidup yang cenderung dapat meningkatkan tekanan darah seperti kebiasaan merokok. _Pada perempuan risiko hipertensi menjadi lebih tinggi setelah memasuki menopause, dalam hal ini faktor hormonal yaitu estrogen bisa menjadi salah satu predisposisinya (Kemenkes Direktorat PPTM Subdit Pengendalian Penyakit Jantung Dan Pembuluh Darah, 2013). Data ini tidak sejalan dengan hasil penelitian ada kemungkinan disebabkan responden memang dominan perempuan sehingga tidak bisa dibandingkan dengan laki-laki.

Pekerjaan responden paling besar adalah kategori lain-lain (ibu rumah tangga, tidak bekerja) sebesar $68.6 \%$. Berdasarkan laporan RISKESDAS Indonesia-Tahun 2013, prevalensi penyakit hipertensi tertinggi terdapat 
pada kelompok tidak bekerja. Hasil penelitian ini bisa mendukung hasil riset nasional karena kelompok tidak bekerja berada pada kategori lain-lain. Risiko hipertensi pada orang tidak beekrja bisa leboh besar karena kurangnya aktifitas fisik yang teratur. Olah raga yang teratur dapat membantu menurunkan tekanan darah dan bermanfaat bagi penderita hipertensi ringan. Dengan melakukan orah raga aerobik yang teratur, tekanan darah dapat turun, meskipun berat badan belum turun (Kemenkes Direktorat PPTM Subdit Pengendalian Penyakit Jantung Dan Pembuluh Darah, 2013).

Sebagian besar tidak ada riwayat hipertensi dari keluarga (54.3\%), sebagian besar menunjukkan tanda dan gejala hipertensi $(84.3 \%)$ dan sebagian besar tidak pernah merokok (82.9\%). Risiko terjadinya hipertensi primer (esensial) bisa meningkat karena faktor riwayat keluarga dekat yang menderita hipertensi (faktor keturunan). Selain itu peranan eksternal seperti faktor lingkungan lain juga mempunyai peran penting.. Teori ini tidak sejalan dengan hasil penelitian karena sebagian besar responden tidak ada riwayat hipertensi dari keluarganya (ada kemungkinan responden tidak mengetahui dan tidak bisa mengingat riwayat penyakit keluarga terdekatnya baik orang tua maupun saudara kandungnya). Hal ini didukung juga dengan hipertensi yang seringkali tidak menimbulkan keluhan pada penderitanya (silent killer). Tanda dan gejala yang dirasakan responden merupakan respon yang umum juga terjadi pada penyakit selain hipertensi sehingga kurang fokus menentukan tanda gejala hipertensi. Sebagian besar responden tidak pernah merokok karena responden didominasi oleh perempuan $(64.3 \%)$

Hasil analisis hubungan antara faktor obesitas (kegemukan) dengan terjadinya hipertensi diperoleh hasil bahwa tidak ada perbedaan proporsi, dimana $\mathrm{p}$ value $=0.26(\alpha>0,05)$, artinya tidak ada hubungan antara paparan faktor obesitas (kegemukan) dengan terjadinya hipertensi. Hasil penelitian yang menunjukkan adanya hubungan antara faktor obesitas yang diperoleh dari hasil IMT dengan terjadinya hipertensi antara lain Sapitri, et.al.(2016) $(\mathrm{p}=0.002)$ dan Mahendrappa (2014) $(\mathrm{p}=0.000)$. Hasil ini tidak sejalan dengan hasil penelitian karena sebagian besar IMT responden tidak obesitas, kemungkinan responden 
sudah menjaga pola makannya sehingga tidak sampai obesitas dan usia dewasa menengah ke dewasa tua lemak tubuh kita juga semakin mengecil.

Hasil analisis hubungan antarafaktor aktifitas fisik dengan terjadinya hipertensi diperoleh hasil bahwa ada perbedaan proporsi dengan $\mathrm{p}$ value $=$ $0.049(\alpha<0,05)$, artinya ada hubungan antara paparan faktor aktifitas fisik dengan terjadinya hipertensi. Dari hasil analisis diperoleh pula nilai $\mathrm{OR}=0.25$, artinya pasien yang melakukan aktifitas fisik dengan dengan skor lebih dari 3 mempunyai peluang 0.25 kali untuk mengalami hipertensi dibandingkan dengan pasien yang terpapar aktifitas fisik dengan skor 3 atau kurang. Bagi penderita hipertensi ringan aktifitas seperti olah raga yang teratur diketahui dapat membantu menurunkan tekanan darah dan bermanfaat bagi kebugaran. Olahraga yang bisa dilakukan untuk menurunkan takanan darah diantaranya aerobik yang teratur, namun demikian berat badan belum tentu mengalami penurunan (Kemenkes Direktorat PPTM Subdit Pengendalian Penyakit Jantung Dan Pembuluh Darah, 2013). Hasil penelitian terkait aktifitas fisik ini sejalan dengan hasil penelitian Sapitri $(2016)(\mathrm{p}=0.000)$

dan

Andria $(2013)(\mathrm{p}=0.000)$.

Hasil analisis hubungan antara faktor konsumsi garam dengan terjadinya hipertensi diperoleh hasil bahwa tidak ada perbedaan proporsi dengan $\mathrm{p}$ value $=1.000(\alpha>0,05)$, artinya tidak ada hubungan antara faktor konsumsi dengan terjadinya hipertensi. Penelitian ini sesuai dengan penelitian yang dilakukan pada masyarakat urban Shimoga ditemukan prevalensi hipertensi $25.83 \%$ dengan 95\% CI: 24.4\%-31.3\% (laki-laki: $27.3 \%$ dan wanita : 24.36\%). Faktor risiko independen hipertensi adalah umur_konsumsi garam berlebih, IMT tinggi, lingkar lengan besar, dan kurangnya aktifitas fisik (Mahendrappa, 2014).

Hasil analisis hubungan antara faktor konsumsi garam dengan terjadinya hipertensi diperoleh hasil bahwa tidak ada perbedaan proporsi dengan $\mathrm{p}$ value $=1.000(\alpha>0,05)$, artinya faktor konsumsi tidak hubungam dengan dengan terjadinya hipertensi. 


\section{SIMPULAN}

Hipertensi adalah suatu keadaan dimana tekanan darah sistolik $\geq 140 \mathrm{mmHg}$ dan atau tekanan darah diastolik $\geq$ 90mmHg. Faktor risiko hipertensi ada dua yaitu faktor risiko yang tidak dapat dimodifikasi seperti usia, jenis kelamin dan genetik serta faktor risiko yang dapat dimodifikasi seperti kegemukan, merokok, kurang aktifitas fisik, konsumsi garam berlebih, dislipidemia , konsumsi alkohol serta psikososisal dan stres. ). Hipertensi merupakan penyakit kronis yang sering tanpa gejala, kondisi klinis menghendaki terapi jangka panjang yang terus menerus untuk kontrol yang efektif. Kejadian hipertensi lebih tinggi pada usia lanjut, ditambah adanya fakta resisten terhadap obat anti hipertensi sehingga mendukung terjadinya penyakit kardiovaskuler akut. Faktor-faktor yang berhubungan dengan kejadian hipertensi pada usia dewasa menjadi fenomena menarik untuk diteliti.

Ada hubungan antara faktor usia dan kurang aktifitas fisik dengan terjadinya hipertensi pada usia dewasa. Jenis kelamin, riwayat keluarga, kegemukan, merokok, konsumsi garam dan faktor psikologis tidak ada hubungannya dengan terjadinya hipertensi pada usia dewasa. Variabel yang berhubungan bermakna dengan terjadinya hipertensi adalah variabel usia. Sedangkan variabel obesitas (kegemukan) dan aktifitas fisik sebagai variabel konfonding. Hasil analisis didapatkan Odd Ratio OR) dari variabel usia adalah 2.9, artinya pasien pada usia dewasa menengah ke atas akan mengalami hipertensi 2.9 kali lebih tinggi dibandingkan pasien belum dewasa setelah dikontrol variabel obesitas (kegemukan) dan aktifitas fisik. Berdasarkan hasil analisis multivariat menunjukkan bahwa faktor usia merupakan faktor risiko yang paling berhubungan dengan terjadinya hipertensi.

Rekomendasi bagi institusi pelayanan kesehatan diharapkan mampu memberikan asuhan yang menekankan pada aspek promotif dan preventif terhadap pasien yang mempunyai riwayat hipertensi. Asuhan promotif difokuskan pada pasien yang melakukan kontrol secara rutin untuk menekan dan menghilangkan kejadian komplikasi lanjut darii hipertensi. Penelitian ini dapat dijadikan rujukan untuk melakukan penelitihan lanjutan 
dalam meningkatkan pengetahuan dan pemahaman tentang hipertensi walaupun penelitian terkait hipertensi sudah banyak dilakukan namun guna menambah wawasan lebih jauh perlu juga mencari fenomena-fenomena terbaru terkait hipertensi.

\section{UCAPAN TERIMA KASIH}

Peneliti mengucapkan terimakasih kepada Poltekkes Kemenkes Jakarta III sebagai donator dana penelitian, Kepala Kantor PTSP Kota Administrasi Jakarta Timur, Kepala Kantor Kesbang dan Politik Kota Administrasi Jakarta Timur dan Suku Dinas Kesehatan Kota Administrasi Jakarta Timur yang memberikan ijin pelaksanaan penelitian serta Puskemas Kelurahan Rawamangun sebagai tempat penelitian.

\section{DAFTAR RUJUKAN}

American Nurses Association (ANA), 1985 In Burns, N. \& Grove, S.K., 2001. The Practice of Nursing Research: Conduct, Critique \& Utilization. 4thEdition ed., Pennsylvania: W.B. Saunders Company.

Andria, K. M. (2011). Hubungan Antara Perilaku Olah Raga, Stres Dan Pola Makan Dengan Tingkat Hipertensi Di Kecamatan Sukolilo Kota Surabaya. Jurnal Promkes Vol 1 No 2 Desember 2011, 111117.
Ardiani, H., Saraswati, L.D. \& Susanto, H.S., 2015. Risk Factors of Hypertension in Menopausal Women in Rejomulyo , Madiun., 19(2), pp.61-66.

Badan Penelitian dan Pengembangan Kesehatan Departemen Kesehatan RI. (2013). Riset Kesehatan Dasar. Jakarta : CV Kiat Nusa.

Jolly, S.E. et al., 2015. Prevalence of Hypertension and Associated Risk Factors in Western Alaska Native People: The Western Alaska Tribal Collaborative for Health ( WATCH ) Study. , 17(10).

Kementerian Kesehatan RI, 2013. Pedoman Teknis Penemuan Dan Tata Laksana Hipertensi. Jakarta : Kementerian Kesehatan.

Krisnawati, F., Basuki, B. \& Nainggolan, G., 2006. Job stressors and other risk factors related to the risk of hypertension among selected employees in Jakarta. , 15(3), pp.177-184.

Lewis, S. L., Heitkemper, M. M., Dirksen, S. R., O'brien, P. G., \& Bucher, L.2007. Medical Surgical Nursing: Assesment and Management of Clinical Problems. Sevent Edition. USA: Mosby Elsevier.

Mahendrappa, S.K. \& Satyanaraya, T. (2014). Original Article A Study On Prevalence Of Hypertension And Its Risk Factors, 3(18), 48764880.

http://doi.org/10.14260/jemds/201 $4 / 2527$ 
Rajan, P., Kumar, V., A., 2015.

Original Article a Study on Risk

Factors for Hypertension in Rural Area , 4(64), pp.11135-11145.

Prajapati, D. \& Kedia, G., 2015.

Prevalence Of Hypertension And Its Risk Factors Among Class Iii And Class Iv Government Employees In Ahmedabad. , 6(4), pp.496-499.

Sapitri, Suyanto, R., 2016. Analisis Faktor Risiko Kejadian Hipertensi Pada MAsyarakat Di Pesisir Sungai Siak Kecamatan Rumbai Kota Pekanbaru., 3(1), pp.1-15.

Sorof dalam Martino, F. et al., 2013. Hypertension In Children And Adolescents Attending A Lipid Clinic. , pp.1573-1579.
Sudhana, T.\&, 2012. Prevalensi Dan Gambaran Faktor Risiko Hipertensi Pada Usia Dewasa DI Wilayah Kerja Puskesmas Tabanan II Periode Mei 2012.

Volpe, M. \& Tocci, G., 2013. Olmesartan in the Treatment of Hypertension in Elderly Patients: a Review of the Primary Evidence. , pp.987-998.

Wainwright, N.W.J. et al., 2014. Social Adversity Experience and Blood Pressure Control Following Antihypertensive Medication Use in a Community Sample of Older Adults. , pp.456-463. 